AL IBTIDA: JURNAL PENDIDIKAN GURU MI (2018) Vol 5 (1) : 1-10

DOI: http://dx.doi.org/ 10.24235/al.ibtida.snj.v5i1.1877

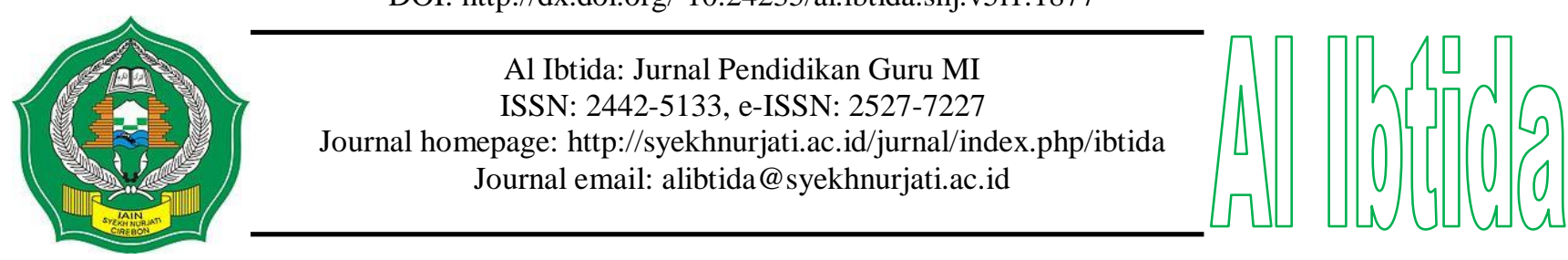

\title{
Keefektifan Model Show and Tell untuk Meningkatkan Keterampilan Berkomunikasi pada Materi Proklamasi Kemerdekaan Siswa Kelas V SD Negeri Babalan
}

\author{
Irma Arviani* \\ *Program Studi Pendidikan Guru Sekolah Dasar, Fakultas Ilmu Pendidikan, \\ Universitas PGRI Semarang \\ Email: irmaarviani.ia@gmail.com \\ Khusnul Fajriyah** \\ **Program Studi Pendidikan Guru Sekolah Dasar, Fakultas Ilmu Pendidikan, \\ Universitas PGRI Semarang \\ Email: khusnulfajriyah88@gmail.com
}

Received 21 August 2017; Received in revised form: 05 March 2018; Accepted 31 March 2018

Publish Online: 28 June 2018

\begin{abstract}
Abstrak
Latar belakang yang mendorong penelitian ini adalah 1) guru masih menggunakan metode ceramah dalam pembelajaran; 2) belum diterapkannya model dan metode yang bervariatif; 3) pembelajaran masih bersifat teacher center; 4) kurangnya aktivitas siswa dalam pembelajaran; 5) masih rendahnya keterampilan berkomunikasi pada mata pelajaran IPS siswa kelas V SD Negeri Babalan. Tujuan yang hendak dicapai dalam penelitian ini adalah mengetahui keefektifan model pembelajaran Show and Tell untuk meningkatkan keterampilan berkomunikasi pada materi proklamasi kemerdekaan siswa kelas V SD Negeri Babalan. Jenis Penelitian ini adalah penelitian kuantitatif dalam bentuk True Exprimental Design dengan Design Posttest-Only Control Design. Populasi dalam penelitian ini adalah keseluruhan siswa kelas V SDN Babalan. Sampel yang diambil adalah 23 siswa Kelas Eksperimen dan 23 siswa Kelas Kontrol dengan menggunakan teknik Cluster Random Sampling. Data penelitian ini diperoleh melalui instrumen penelitian dokumentasi, tes, dan lembar observasi. Berdasarkan hasil analisis akhir yang telah dilakukan terlihat dari persentase keterampilan berkomunikasi siswa yang menunjukkan pembelajaran tanpa menggunakan model pembelajaran show and tell tuntas dengan persentase $17,39 \%$ dan belum tuntas dengan persentase $82,61 \%$. Sedangkan kelas yang diberi perlakuan menggunakan model pembelajaran show and tell tuntas dengan persentase $86,96 \%$ dan belum tuntas dengan persentase $13,04 \%$. Hal tersebut diperkuat dengan hasil perhitungan $t_{\text {hitung }}=5,347$ selanjutnya dibandingkan dengan $t_{\text {tabel }}=2,015$ pada taraf signifikan $\alpha=5 \%$. Hasil ini menunjukkan bahwa $t_{\text {hitung }}>\mathrm{t}_{\text {tabel }}$ yaitu 5,347 > 2,015. Sehingga dapat disimpulkan bahwa model show and tell efektif untuk meningkatkan keterampilan berkomunikasi kelas V SD Negeri Babalan.
\end{abstract}

Kata kunci: keefektifan, model show and tell, keterampilan berkomunikasi 


\begin{abstract}
The background that encourages this research is 1) the teacher still uses the lecturing method in learning; 2) not yet applied varied models and methods; 3) the learning is still the teacher center; 4) the lack of student activity in the learning; 5) the low communication skills in the IPS learning class V SD Negeri Babalan. The purpose of this research is to know the effectiveness of Show and Tell learning model to improve communication skill in material of proclamation of independence of $\mathrm{V}$ class student of SD Negeri Babalan. This type of research is quantitative research in the form of True Experimental Design with Posttest-Only Control Design. The population in this study is the overall students in grade V SDN Babalan. Samples taken were 23 students of Experiment Class and 23 Class Control students by using Cluster Random Sampling technique. This research data is obtained through instrument of research of documentation, test, and observation sheet. Based on result of final analysis which have been done seen from percentage of communication skill of student which show lesson without using show and tell model complete with percentage $17,39 \%$ and not yet complete with percentage $82,61 \%$. While the treated classes using show and tell learning model complete with $86.96 \%$ percentage and not yet completed with the percentage of $13.04 \%$. This is reinforced with the result of $t$ calculation $=5.347$ then compared with $t$ table $=2.015$ at significant level $\alpha=5 \%$. This result indicates that $\mathrm{t}$ hitung $>\mathrm{t}$ table is $5,347>2,015$. So it can be concluded that the show and tell model is effective for improving communication skills class V SD Negeri Babalan.
\end{abstract}

Keywords: effectiveness, learning model show and tell, communication skills

\title{
PENDAHULUAN
}

Undang-Undang Republik Indonesia Nomor 20 tahun 2003 tentang Sistem Pendidikan Nasional dalam Bab 1 pasal 1 menyebutkan bahwa pendidikan nasional memiliki fungsi dalam mengembangkan kemampuan dan membentuk watak serta peradaban bangsa yang bermartabat dalam rangka mencerdaskan kehidupan bangsa. Pendidikan Nasional bertujuan untuk mengembangkan potensi peserta didik agar menjadi manusia yang beriman dan bertakwa kepada Tuhan yang Maha Esa, berakhlak mulia, sehat, berilmu, cakap, kreatif, mandiri, dan menjadi warga negara yang demokratis serta tanggung jawab.

Salah satu faktor yang mempengaruhi mutu pendidikan adalah kompetensi guru. Untuk itu guru dalam melaksanakan perannya sebagai pendidik, pengajar, pemimpin, dan administrator harus mampu melayani peserta didik yang dilandasi dengan kesadaran, keyakinan, kedisiplinan, dan tanggung jawab secara optimal. Sehingga memberikan pengaruh positif terhadap perkembangan siswa secara optimal, baik fisik maupun psikis. Suatu keberhasilan dalam mengajar merupakan kebahagiaan tersendiri bagi seorang guru. Akan tetapi keberhasilan tersebut tetap dipengaruhi oleh hasil belajar siswa yang dapat memenuhi kriteria ketuntasan minimal. Hasil belajar yang dikemukakan oleh Bloom dalam Saputra, dkk (2015: 17) "dalam proses pembelajaran siswa harus mencapai 3 ranah, yaitu kognitif, afektif, dan psikomotorik". Oleh 
karena itu guru harus mempunyai 4 kompetensi diantaranya kompetensi pedagogik, kompetensi sosial, kompetensi kepribadian, dan kompetensi profesional.

Susanto (2013: 144) mengatakan bahwa salah satu aspek yang dikembangkan dalam pendidikan IPS adalah aspek psikomotor (keterampilan) yang dapat meningkatkan kecakapan dasar siswa (berkomunikasi). Keterampilan berkomunikasi sangat diperlukan untuk mencapai keberhasilan dalam belajar dan hubungan dengan lingkungan sekitar. Aktivitas anak yang dapat dilakukan yaitu berinteraksi dengan orang-orang yang ada di sekitarnya, sehingga dapat melatih anak untuk terampil berkomunikasi. Dengan menyampaikan gagasan, anak akan menemukan pengalaman, meningkatkan pengetahuannya dan mengembangkan bahasanya. Keterampilan berkomunikasi harus dikuasai oleh peserta didik sekolah dasar karena keterampilan ini secara langsung berkaitan dengan seluruh proses belajar peserta didik di sekolah dasar. Keberhasilan belajar peserta didik dalam mengikuti proses kegiatan belajar mengajar di sekolah sangat ditentukan oleh penguasaan kemampuan berkomunikasi mereka. Dengan keterampilan komunikasi, siswa akan mudah mengkomunikasikan berbagai hal yang menyangkut materi pembelajaran, baik secara lisan maupun tulisan. Hal tersebut sesuai dengan penelitian yang dilakukan oleh Trislijayanti, Sriasih, dan Sutresna (2015) yang mengatakan bahwa komunikasi yang baik memiliki peranan penting dalam upaya siswa membentuk suatu pemahaman terhadap materi pembelajaran.

Nejawati (2017) dalam penelitiannya telah mengemukakan permasalahan rendahnya keterampilan berkomunikasi siswa sekolah dasar. Bagi banyak siswa, kegiatan berkomunikasi lisan atau berbicara secara resmi (di depan banyak orang), meskipun itu hanya dalam bentuk mengajukan pertanyaan merupakan kegiatan yang sulit untuk dilakukan. Dalam pembelajaran dapat dikatakan hampir tidak ada siswa yang bertanya. Kalau tidak ditunjuk, tidak ada yang berani menjawab pertanyaan, baik pertanyaan siswa lain maupun guru. Padahal di sisi lain, Maufur (2014) dalam penelitiannya mengemukakan bahwa keterampilan berbicara sebagai bagian dari keterampilan komunikasi sangat menunjang seseorang dalam memperoleh keuntungan sosial maupun profesional.

Selain keterampilan berbicara, keterampilan berkomunikasi juga menyangkut keterampilan menulis yang tidak bisa dipandang sepele. Sokhipah, Subyantoro, dan Mardikantoro (2015) dalam penelitiannya juga mengungkapkan bahwa keterampilan menulis merupakan keterampilan yang sangat kompleks yang menuntut sejumlah pengetahuan dan keterampilan sekaligus. Peserta didik perlu memahami bagaimana menulis yang baik dan benar. Tidaklah berlebihan jika dikatakan demikian karena dalam kegiatan menulis banyak persyaratan yang harus dipenuhi di antaranya harus bermakna, jelas, atau lugas, merupakan satu kesatuan, 
singkat dan padat, seta memenuhi kaidah kebahasaan. Oleh karena itu, keterampilan berkomunikasi hendaknya dilatihkan melalui kegiatan pembelajaran di kelas.

Umumnya, guru cenderung menggunakan pendekatan yang konvensional sehingga berpengaruh terhadap keterampilan berkomunikasi siswa. Pembelajaran yang dilakukan masih berpusat pada guru sehingga siswa jarang diberikan kesempatan untuk mengembangkan kemampuan bahasa melalui komunikasi. Keterampilan berkomunikasi yang rendah dapat dipengaruhi oleh pendekatan pembelajaran, metode, media, atau sumber pembelajaran yang digunakan oleh guru (Widiani, Arcana \& Margunayasa: 2014). Hal ini terlihat ketika komunikasi siswa dalam kegiatan pembelajaran, anak masih kurang aktif, belum bisa menjawab pertanyaan dengan baik, dan kurangnya kepercayaan diri dalam menyampaikan gagasan di depan kelas. Susanto (2013:53) mengemukakan bahwa keefektifan siswa dalam belajar, tampak apabila siswa dapat terlibat secara aktif, baik mental, fisik, maupun sosialnya. Artinya pembelajaran kurang efektif apabila keterampilan berkomunikasi rendah, baik berkomunikasi lisan, tulisan atau isyarat.

Berdasarkan penelitian yang dilakukan oleh Musfiroh (2011) yang berjudul "Show and Tell Edukatif untuk Pengembangan Empati, Afiliasi-Resolusi Konflik, Dan Kebiasaan Positif Anak Usia Dini”, hasil uji lapangan terbatas menunjukkan peningkatan yang cukup signifikan pada skor awal dan skor akhir. Sebelum kegiatan Show and Tell, rerata skor empati mencapai 8,05 skor afiliasi dan resolusi konflik 6,53 dan skor kebiasaan positif 8,79. Bila dikonversikan pada kriteria maka skor tersebut pada level "baik". Setelah kegiatan Show and Tell terjadi sedikit kenaikan skor empati, yaitu mencapai rerata skor 9,01 skor afiliasi dan konflik 7,40 dan skor kebiasaan positif 9,94 dengan rentang kenaikan rerata sebesar 0,98, 0,87 dan 1,15. Hal ini mengindikasikan bahwa show and tell cukup efektif untuk meningkatkan kemampuan empati, afiliasi resolusi konflik, dan kebiasaan positif anak usia dini. Hasil penelitian lain yang dilakukan oleh Pangestuti (2016) menunjukkan bahwa show and tell dapat meningkatkan kemampuan berbicara peserta didik. Hal ini dibuktikan dari diperoleh $t$ hitung pada kelas eksperimen sebesar $-8,380$ dan sig 0,000. Nilai sig menyatakan <0,05 maka dapat disimpulkan bahwa ada perbedaan yang signifikan hasil pretest dan posttest kelompok eksperimen. Apabila dilihat dari rata-rata hasil pretest 6,63 menjadi 8,47 pada hasil posttest kelompok eksperimen yang berarti ada peningkatan kemampuan berbicara anak sebesar 1,9. Model Show and Tell terdiri atas tahapan kegiatan show atau menunjukkan sesuatu kepada audiens dan tell menjelaskan atau mendeskripsikan sesuatu yang sedang ditunjukkan tersebut. Deskripsi dalam hal ini meliputi bentuk, warna, ukuran, komposisi, dan guna unsur. Tell dalam Show and Tell juga mengandung pengertian menjelaskan, yakni menjelaskan asal muasal benda yang 
ditunjukkan, menjelaskan fungsi benda secara umum, dan bahkan menjelaskan arti pentingnya benda bagi diri sendiri dan orang lain (Musfiroh dalam Nupus \& Parmiti:2017).

Peristiwa Proklamasi kemerdekaan merupakan salah satu materi dalam mata pelajaran IPS sekolah dasar. Materi tersebut memuat peristiwa yang terjadi sebelum dan saat kemerdekaan Indonesia, sehingga bisa dijadikan bahan untuk siswa menganalisis setiap peristiwa tersebut. Selain itu materi proklamasi kemerdekaan mengajarkan siswa sebagai generasi muda untuk mempunyai tanggung jawab dan kesadaran sebagai generasi penerus bangsa yang harus menghargai perjuangan para pahlawan bangsa yang telah gugur di medan perang demi mencapai arti kata merdeka agar kita dapat mengambil pelajaran di dalamnya sehingga kita dapat membangun bersama menuju Indonesia yang damai dan sejahtera. Namun, hasil wawancara dengan guru kelas menunjukkan bahwa materi proklamasi kemerdakaan ini belum dikuasai siswa secara optimal. Hal demikian juga ditemukan oleh Mahrita \& Muzakir (2014) dalam penelitiannya yakni nilai rata-rata ulangan harian materi proklamasi kemerdekaan SD Kalayan hanya mencapai 65 dan ketuntasan klasikalnya hanya mencapai $68 \%$.

Berdasarkan permasalahan di atas, maka salah satu upaya yang dilakukan penulis untuk meningkatkan keterampilan berkomunikasi adalah dengan menggunakan model Show and Tell. Model Show and Tell adalah suatu model pembelajaran yang membuat siswa aktif dengan cara yang mudah diikuti, nyaman, dan menyenangkan. Model Show and Tell merupakan suatu pembelajaran yang menggunakan suatu benda misalnya foto/gambar, benda-benda, dll yang berhubungan dengan proklamasi kemerdekaan. Melalui pembelajaran model Show and Tell diharapkan siswa mampu berlatih menampilkan dan menceritakan hasil diskusi yang didapat bersama kelompoknya sehingga dapat meningkatkan keterampilan berkomunikasi siswa kelas $\mathrm{V}$ SD Negeri Babalan tahun ajaran 2016/2017. Adapun tujuan dari penelitian ini adalah untuk mengetahui keefektifan model pembelajaran Show and Tell untuk meningkatkan keterampilan berkomunikasi pada materi proklamasi kemerdekaan siswa kelas V SD Negeri Babalan.

\section{METODE PENELITIAN}

Jenis Penelitian ini adalah penelitian kuantitatif dalam bentuk True Exprimental Design. Populasi dalam penelitian ini adalah keseluruhan siswa kelas V SDN Babalan. Sampel yang diambil adalah 23 siswa Kelas Eksperimen dan 23 siswa Kelas Kontrol dengan menggunakan teknik Cluster Random Sampling. Desain penelitian yang digunakan adalah Posttest-Only Control Design. Terdapat dua variabel dalam penelitian ini yaitu variabel bebas dan variabel terikat. Variabel bebas dalam penelitian ini adalah model pembelajaran show and tell. Variabel terikat dalam penelitian ini adalah keterampilan berkomunikasi siswa kelas $\mathrm{V}$ pada materi proklamasi kemerdekaan SD Negeri Babalan. 
Teknik pengumpulan data yang digunakan dalam penelitian ini adalah dokumentasi, observasi dan tes. Teknik dokumentasi digunakan untuk memperoleh data yang mendukung proses penelitian, seperti data siswa, dan lain-lain. Sementara itu, teknik observasi digunakan untuk memperoleh data tentang aktivitas siswa dalam proses pembelajaran menggunakan model show and tell. Selanjutnya, tes digunakan untuk memperoleh data tentang nilai hasil belajar siswa setelah menggunakan model pembelajaran show and tell. Adapun teknik analisis data yang digunakan adalah analisis skor lembar observasi dan uji t-tes.

\section{HASIL DAN PEMBAHASAN}

Berdasarkan hasil observasi diperoleh bahwa nilai Ulangan Tengah Semester (UTS) dari 46 siswa kelas V yang lulus KKM hanya 8 siswa dengan persentase ketuntasan $17,4 \%$. Hal ini diperkuat dengan hasil wawancara yang mengungkapkan bahwa guru mengalami kesulitan untuk menyamakan kemampuan siswa dalam berkomunikasi menyampaikan gagasan. Selanjutnya dilaksanakan pembelajaran IPS yang dilakukan pada kedua kelompok, yaitu pada kelompok kelas eksperimen dan kontrol. Data pada lembar observasi keterampilan komunikasi diperoleh setelah dilaksanakan pembelajaran dengan menggunakan model Show and Tell pada kelas eksperimen dan pembelajaran secara konvesional pada kelas kontrol. Penelitian ini bertujuan untuk mengetahui keefektifan model Show and Tell terhadap keterampilan berkomunikasi siswa kelas V SD Negeri Babalan.

Pada pembelajaran dengan menggunakan model Show and Tell siswa menjadi lebih aktif dan tertarik untuk mengikuti pembelajaran. Hal ini terjadi karena sebelumnya model Show and Tell belum pernah dilaksanakan dalam kelas, sehingga perhatian siswa menjadi terpusat pada pembelajaran. Data hasil observasi keterampilan berkomunikasi siswa dapat dilihat pada tabel dan gambar berikut.

Tabel 1. Nilai Keterampilan Berkomunikasi

\begin{tabular}{lll}
\hline Keterangan & Kelas Eksperimen & Kelas Kontrol \\
\hline Nilai Terendah & 64,6 & 52,1 \\
\hline Nilai Tertinggi & 83,3 & 77,1 \\
\hline Rata-rata & 77,26 & 69,55 \\
\hline
\end{tabular}

Berdasarkan tabel 1 di atas diperoleh data hasil lembar observasi keterampilan berkomunikasi pada kelas eksperimen dan kelas kontrol diperoleh rata-rata tertinggi terdapat pada kelas eksperimen. Hal ini menunjukkan bahwa keterampilan berkomunikasi pada siswa kelas eksperimen lebih baik dibandingkan keterampilan berkomunikasi pada siswa kelas kontrol. Dengan demikian dapat disimpulkan bahwa model Show and Tell pada kelas eksperimen lebih baik dibandingkan model konvensional pada kelas kontrol. Data tabel 1 tersebut dapat disajikan ke dalam bentuk diagram berikut ini: 


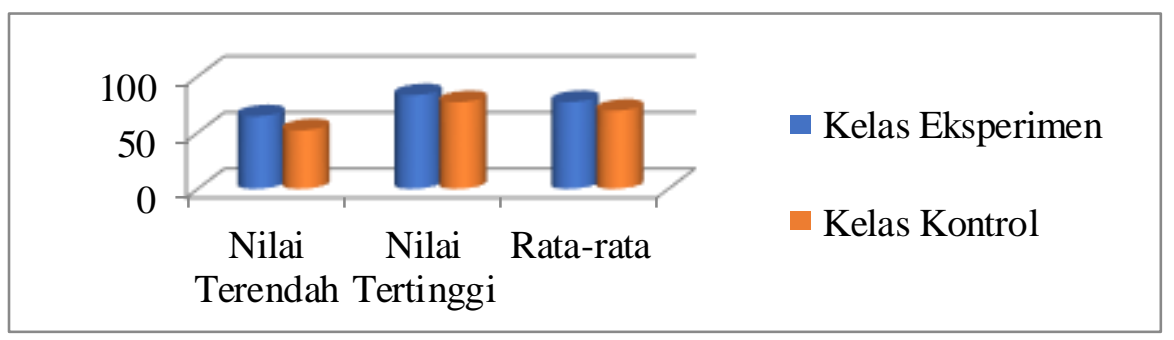

Gambar 1. Diagram Keterampilan Berkomunikasi

Selain observasi untuk mengetahui keterampilan berkomunikasi, peneliti juga melakukan posttest untuk mengetahui hasil belajar pada kelas eksperimen yang menggunakan model Show and Tell dan kelas kontrol yang menggunakan model konvensional. Data hasil belajar posttest kelas eksperimen dan kontrol dapat dilihat pada tabel 2 berikut:

Tabel 2. Nilai Posttest Kelas Eksperimen dan Kelas Kontrol

\begin{tabular}{lll}
\hline Keterangan & Kelas Eksperimen & Kelas Kontrol \\
\hline Nilai Terendah & 66,6 & 56,6 \\
\hline Nilai Tertinggi & 100 & 96,6 \\
\hline Rata-rata & 85,03 & 75,62 \\
\hline
\end{tabular}

Berdasarkan tabel 2 di atas nilai terendah hasil belajar posttest yang diperoleh siswa pada kelas eksperimen sebesar 66,6 dan kontrol sebesar 56,6. Sedangkan nilai tertinggi hasil belajar posttest yang diperoleh siswa pada kelas eksperimen sebesar 100 dan kontrol sebesar 96,6. Serta diperoleh nilai rata-rata pada kelas eksperimen sebesar 85,03 dan kontrol sebesar 75,62. Pada kelompok kelas eksperimen dan kontrol terdapat perbedaan hasil belajar yang signifikan. Dengan data tersebut dapat disimpulkan bahwa hasil belajar posttest kelas eksperimen yang menggunakan model pembelajaran Show and Tell lebih baik dibandingkan hasil belajar kelas kontrol yang menggunakan model konvensional.

Penelitian ini yang berjudul Keefektifan Model Show and Tell untuk Meningkatkan Keterampilan Berkomunikasi pada Materi Proklamasi Kemerdekaan Siswa Kelas V SD Negeri Babalan menggunakan True Experimental Design. Subjek yang dijadikan sampel penelitian adalah kelas VA dan VB SD Negeri Babalan. Pada kelas eksperimen diberikan perlakuan dengan menggunakan model Show and Tell. Sedangkan pada kelas kontrol diberikan perlakuan dengan menggunakan pembelajaran secara konvensional. Peneliti menggunakan dua data yang akan dianalisis, data yang pertama adalah lembar observasi keterampilan berkomunikasi siswa yang telah diberikan perlakuan dengan menggunakan model Show and Tell. Data kedua yang akan dianalisis adalah data hasil belajar siswa

Pada hasil belajar posttest diperoleh rata-rata nilai kelas eksperimen sebesar 85,03 dan nilai rata-rata nilai kelas kontrol sebesar 75,62. Pada kedua kelas sampel terdapat perbedaan hasil 
belajar yang signifikan, hasil belajar posttest pada kelas eksperimen lebih baik dibandingkan hasil belajar posttest pada kelas kontrol. Perbedaan hasil belajar pada kedua kelompok kelas dikarenakan perlakuan yang diberikan pada masing-masing kelas berbeda-beda. Respon siswa pada kelas eksperimen yang menggunakan model Show and Tell lebih antusias dan aktif saat pembelajaran. Pembelajaran berjalan lancar dan menarik perhatian siswa di dalam kelas. Keaktifan ini dikarenakan ketertarikan pada cara serta suasana pembelajaran yang sebelumnya belum pernah dilaksanakan. Pada penelitian ini peneliti ingin mengetahui keefektifan model Show and Tell untuk meningkatkan keterampilan berkomunikasi pada materi proklamasi kemerdekaan siswa kelas V SD Negeri Babalan. Data pada penelitian ini diperoleh dari lembar observasi keterampilan berkomunikasi dan hasil belajar posttest. Selanjutnya setelah diperoleh data hasil belajar posttest dilakukan uji normalitas untuk mengetahui data berasal dari data yang berdistribusi normal atau tidak.

Data hasil observasi keterampilan berkomunikasi pada kelas eksperimen dan kelas kontrol diuji dengan menggunakan uji t dua sampel. dengan jumlah dk=44 dan taraf kesalahan $5 \%$ diperoleh nilai $t_{\text {tabel }}=2,02$. Hasil perhitungan uji $t$ diperoleh nilai $t_{\text {hitung }}=5,347$. Karena nilai $t_{\text {hitung }}>\mathrm{t}_{\text {tabel }}$ yaitu 5,347>2,02 maka hipotesis yang diajukan dapat diterima. Dengan demikian dapat disimpulkan bahwa keterampilan berkomunikasi siswa yang menggunakan model pembelajaran Show and Tell lebih baik daripada hasil belajar model konvensional. Uji t dua sampel dengan menggunakan hasil belajar posttest kelas eksperimen dan kontrol dengan jumlah $\mathrm{dk}=44$ dan taraf kesalahan $5 \%$ diperoleh nilai $\mathrm{t}_{\text {tabel }}=2,02$. Hasil perhitungan uji $\mathrm{t}$ diperoleh nilai $t_{\text {hitung }}=2,91$. Karena nilai $t_{\text {hitung }}>\mathrm{t}_{\text {tabel }}$ yaitu 2,91 $>2,02$ maka hipotesis yang diajukan dapat diterima. Dengan demikian dapat disimpulkan bahwa hasil belajar pada kelas yang menggunakan model pembelajaran Show and Tell lebih baik daripada model konvensional.

Kemampuan berkomunikasi siswa kelas V SD Negeri Babalan yang rendah perlu ditingkatkan dengan diberikan pembelajaran yang tepat. Pembelajaran yang dirasa tepat untuk meningkatkan kemampuan berkomunikasi siswa dengan menggunakan model pembelajaran Show and Tell. Pembelajaran menggunakan model Show and Tell membuat siswa aktif mengikuti pembelajaran, karena pembelajaran ini membiasakan siswa untuk bertutur kata atau mengungkapkan pendapat atau gagasan yang di miliki siswa sehingga rasa percaya diri siswa dapat meningkat baik saat diskusi maupun di depan kelas. Selain itu pembelajaran ini juga menarik perhatian siswa karena baru pertama kali dilaksanakan di dalam kelas. Dengan demikian pembelajaran Show and Tell dapat meningkatkan kemampuan berkomunikasi dengan baik. Hal ini sesuai dengan teori Patsalides (dalam Musfiroh, 2011: 9) yang mengemukakan manfaat model show and tell adalah untuk mengembangkan beberapa aspek, salah satunya adalah meningkatkan rasa percaya diri anak. Percaya diri dalam hal ini yaitu percaya diri dalam 
mengungkapkan pendapat dan berkomunikasi. Pembelajaran yang tidak menarik membuat siswa menjadi bosan dan hasil belajar rendah.

Dalam pembelajaran diperlukan variasi dengan memperhatikan kemampuan dan metode yang digunakan guru agar siswa tertarik sehingga hasil belajar menjadi meningkat. Pembelajaran yang dirasa mampu meningkatkan hasil belajar siswa kelas V SD Negeri Babalan yaitu dengan menggunakan model pembelajaran Show and Tell. Aktivitas belajar sebelum menggunakan model pembelajaran Show and Tell siswa kurang aktif mengikuti pembelajaran, ditunjukkan dengan hasil belajar yang rendah di bawah rata-rata sebesar 74. Untuk meningkatkan hasil belajar dan menarik perhatian siswa agar pembelajaran berjalan aktif maka perlu diberikan perlakuan yang berbeda. Peneliti di sini memilih menggunakan model pembelajaran Show and Tell, pembelajaran ini memiliki banyak kelebihan yang mampu meningkatkan kemampuan berkomunikasi, hasil belajar serta membuat siswa menjadi aktif mengikuti pembelajaran. Hal ini sesuai dengan teori Menurut Gagne (dalam Susanto), belajar dimaknai sebagai suatu proses untuk memperoleh motivasi dalam pengetahuan, keterampilan, kebiasaan, dan tingkah laku. Suyanto (2005: 145) juga menyatakan bahwa "model show and tell sangat baik untuk mengungkap kemampuan, perasaan, dan keinginan anak". Teori dapat diterima dan sesuai dengan hasil penelitian yang diperoleh.

Berdasarkan hasil penelitian, terbukti dan dapat diterima bahwa kemampuan berkomunikasi dan hasil belajar siswa menjadi lebih meningkat setelah diberikan pembelajaran dengan menggunakan model Show and Tell. Siswa menjadi lebih aktif dalam berkomunikasi dan mengungkapkan pendapat yang ingin di sampaikan. Sehingga dapat dikatakan pembelajaran menggunakan model Show and Tell efektif untuk meningkatkan keterampilan berkomunikasi pada materi proklamasi kemerdekaan siswa kelas V SD Negeri Babalan.

\section{SIMPULAN}

Berdasarkan hasil penelitian dan analisis data, dapat disimpulkan bahwa model Show and Tell efektif untuk meningkatkan keterampilan berkomunikasi pada materi proklamasi kemerdekaan siswa kelas V SD Negeri Babalan. Nilai keterampilan berkomunikasi dan hasil belajar pada kelas eksperimen yang menggunakan model Show and Tell memiliki nilai rata-rata yang lebih baik dibandingkan pada kelas kontrol yang menggunakan pembelajaran konvensional. Ketertarikan dan keaktifan siswa saat mengikuti pembelajaran dengan menggunakan model Show and Tell lebih terlihat dibandingkan dengan keaktifan siswa yang menggunakan pembelajaran secara konvensional. Keberanian dan rasa percaya diri siswa dalam menyampaikan gagasan dengan menggunakan model show and tell lebih tinggi. 


\section{DAFTAR PUSTAKA}

Depdiknas. (2003). Undang-Undang No 20 Tahun 2003 tentang Sistem Pendidikan Nasional. Jakarta: Sekretariat Negara

Mahrita dan Muzakir, A. (2014). Meningkatkan Hasil Belajar Siswa pada Materi Peristiwa Sekitar Proklamasi Kemerdekaan Indonesia Melalui Model Pembelajaran Role Playing yang Divariasikan dengan Student Teams Achievement Divisions (STAD) Di Kelas V SDN Kelayan Selatan 9 Banjarmasin. Jurnal Paradigma, 9(2), 1-6

Maufur, Syibli. (2014). Konsep Pembelajaran Berbicara di MI (Suatu Pendekatan dan Praktik Dalam Pembelajaran). Al Ibtida: Jurnal Pendidikan Guru MI, 1(2)

Musfiroh, T. (2011). Show and Tell Edukatif untuk Pengembangan Empati, Afiliasi-resolusi Konflik, dan Kebiasaan Usia Positif Anak Dini. Jurnal Kependidikan, 41(2), 129-143

Nejawati, A. (2017). Upaya Meningkatkan Keterampilan Berbicara Siswa dengan Menerapkan Metode Show and Tell Pada Pembelajaran Bahasa dan Sastra Indonesia. BIORMATIKA Jurnal Ilmiah FKIP Universitas Subang, 3(2)

Nupus, M.H., dan Parmiti, D.P,. (2017). Peningkatan Keterampilan Berbicara Melalui Penerapan Metode Show And Tell Siswa SD Negeri 3 Banjar Jawa. Jurnal Ilmiah Sekolah Dasar, 1 (4), 198-203.

Pangestuti, L. (2016). Pengaruh Metode Show and Tell Terhadap Kemampuan Berbicara Anak Kelompok A di Taman Kanak-Kanak. Jurnal Pendidikan Anak Usia Dini, 5(9).952-962

Saputra, H.J., dkk. (2015). Suplemen Pengembangan Pendidikan IPA SD. Semarang: PGSD FIP Universitas PGRI Semarang

Sokhipah, W.L., Subyantoro, dan Mardikantoro, H.B. (2015). Keefektifan Model Show Not Tell dan Mind Map Pada Pembelajaran Menulis Teks Eksposisi Berdasarkan Minat Peserta Didik Kelas X SMK. Seloka: Jurnal Pendidikan Bahasa dan Sastra Indonesia, 4(2). 7277

Susanto, A. (2013). Teori Belajar dan Pembelajaran di Sekolah Dasar. Jakarta: Prenada Media Group

Suyanto, S. (2005). Konsep Dasar Pendidikan Anak Usia Dini. Jakarta: Direktorat Pembinaan Pendidikan Tenaga Kependidikan dan Ketegagaan Perguruan Tinggi.

Trislijayanti, L. E., Sriasih, S. A. P., dan Sutresna, I. B. (2015). Penggunaan Metode Show And Tell dalam Pembelajaran Bahasa Indonesia untuk Meningkatkan Keterampilan Berbicara Siswa Kelas VII.C di SMP Negeri 1 Seririt Tahun Ajaran 2014/2015. eJournal Jurusan Pendidikan Bahasa dan Sastra Indonesia Undiksha, 3(1)

Widiani, K., Arcana, I.N. dan Margunayasa, I.G. (2014). Pengaruh Metode Pembelajaran Show and Tell Terhadap Keterampilan Berbicara Siswa Kelas V Tahun Pelajaran 2013/2014 Di SD Negeri 1 Sangsit. Jurnal Mimbar PGSD Universitas Pendidikan Ganesha Jurusan PGSD, 2(1) 